Omni-Akuatika, 13 (1): 34-33, 2017
ISSN: 1858-3873 print / 2476-9347 online
Research Article

\title{
Genetic Diversity Approach to Fishery Management Spiny Lobster Southern Waters of Java Based on SWOT Analysis and AHP
}

\author{
Florencius Eko Dwi Haryono $^{\left.{ }^{*}\right)}$, Ambariyanto ${ }^{2,3)}$ \\ ${ }^{*}$ *) Department Marine Science. Faculty Fisheries and Marine Science. Jenderal Soedirman University, Purwokerto \\ 2) Department Marine Science. Faculty Fisheries and Marine Science. Diponegoro University, Semarang \\ 3) Integrated Laboratory of Diponegoro University, Semarang \\ *)Corespondent outhor : marine_2807@yahoo.com
}

Received 06 February 2017; Accepted 22 April 2017; Available online 25 May 2017

\begin{abstract}
Indonesia is an archipelago and tropical country, and known as the centre of mega biodiversity. Tropical spiny lobster consists several species and can survive without water for a certain periods and these excess used to be distributed life conditions. Spiny lobster fisheries become an important issue in Indonesia now, due to the production decrease for some decades, and need more strategy fisheries management. The research have done from February-August 2015 to analyze genetic diversity of spiny lobster in SCJ and SRJ waters, by collecting the lobster randomly at district waters. Spiny lobster were identified morphometric, distribution, abundant, and analysis mtDNA by PCR method to know the kinship at districts waters. Questioners distributed to fisherman, lobster collectors, government, NGO, exporter and lobster expert. Data has been analyzed using SWOT and AHP methods. The fisheries management is based on highest score of management priority. The first priority of fisheries management by approach of diversity genetic of spiny lobster was acquired management is not based on a management authority of each district. The fisheries management required the cooperation of all district in SJW ad SRJ, or integrated management. The conditions for genetically that spiny lobster was a descendant although morphologically live scattered each district water.
\end{abstract}

Keywords : Spiny lobster, management, diversity genetic, SWOT, AHP

\section{Introduction}

Indonesia is an archipelago and tropical country with high biodiversity, include marine resources and knows as the centre of megabiodiversity (Brook at.al. 2006; Ambariyanto 2010). Spiny lobster was an important species because have supported the global food stocks, support fishery production currently around 260,000 tons per year (de Lestang et al, 2015). National spiny lobster production in 2002 until 2012 increased $17,09 \%$ and in 2011 to 2012 increased at $28.54 \%$. While the production of lobster at Central Java Province (CJP) and Special Region of Jogyakarta (SRJ) in 2012-2013 increased $21.5 \%$. SCJ waters consist of Cilacap, Kebumen, Purworejo district waters, and SRJ consist of Kulon Progo, Bantul and Gunung Kidul district waters (Indonesia Fishery Statistics, 2012). SCJ and SRJ waters were known as high catch of lobster.
Lobster was a special shrimp that able to survive without water for a certain period and this excess used to be distributed lively (Landau, 1991), and these advantages lead to high economic value. Tropical lobster consists of several species, family Panulidae, genus Panulirus consists of 19 species, 6 species live in Indonesia waters, namely $P$. homarus Linnaeus (1758), P. pencillatus Olivier (1791), P. longipes A. Milne - Edwards (1868), P. ornatus Fabricus (1798) and $P$. vercicolor Latreille ( 1804 ), $P$. polyphagus. The species is not only live in the Indonesian waters but also found in several places in the Pacific waters (Reddy, 2013; Haryono dan Tjahya, 2008). The tropical spiny lobster widely distribute, from Natal coast of South Africa to French Polynesia in the Pacific. The result of recent research of lobster fishery has decreased very seriously, including distribution, thus causing extremely important to 
assist the process of rigorous taxonomy and management (Lavery et al, 2014).

Shrimp, mud crab and swimming crab has become an important issue explicitly, due to the production were decreasing from $y$ to $y$ and need to manage the marine resources. Some of lobster fisheries management such as Marine Protected Areas (MPAs) (Truelove et al 2015), created and designed for restrictions of fishing area and as a tool for fisheries management (Sanchez et al. 2013), and important step to protect the sea in Europe, in addition to Maritime Spatial Planning/MSP (Solomon and Dross. 2013). Other fisheries management was Community Based Management (CBM), the management to implement local rules in the territorial of sea (Leopold et al. 2013). CBM in fisheries known as Community-Based Fisheries Management (CBFM), management based on the community that the society group managing their fisheries region. Individual Transferable Quota (ITQ) is the ones of fisheries management based on a quota fishing activities. ITQ as part of Total Allowable Catch /TAC which each fisherman catch in percentage quota (Duppont, 2013). Management based on ecosystem conservation involved communities, local customs and culture (Nanloby, et al. 2015). Other fisheries management was Marine Spatial Planning (MSP), a step to access the capabilities and to value a spatial typology for MSP (Jansen, et al. 2013). Management applied to integrated fisheries in coastal regions known as the Integrated Coastal Zone Management (ICZM) (Brenn and Hynes. 2014). Fisheries management system based on Total Allowable Effort (TAE) will be replaced by a system individually transferable unit effort (ITE), as an efficient mechanism to decrease the potential effort (latent effort). Characteristics of lobster fishery is open access or restrictions based on catch. ITE system also effective used to arrange the catching as compensation to environmental resources from declining production of catch (de Lestang, et al. 2015).

Small fishery based on open access system have not implemented controls management. Long term approach to the management of the biological control of fisheries based data used as a basis to make effective management decisions. The health of marine environment can be seen through some indicators. Based on the status of fish exploited commercially, the indicators have been maximum sustainable fishing effort, mortality caused by the capture relative to the average natural mortality, $90 \%$ of the average length were mature eggs females, and abundance in national waters relative to the average abundance in the time series (Froese et al. 2015).

The identification of species analysis based on morphological many irregularities, as result the differences in morphology of larval stage to the adult (Chow et al, 2006). Another factor, such as biology lobster and oceanography, and water quality caused lobster abundant, and pollution can cause genetic diversity (Palero et al. 2009). Based on decline of spiny lobster population productions (Panulirus spp.), Crab (Scyla spp.), and swimming crab (Portunus pelagicus spp.). on January 6, 2015 have issued Regulation No. $1 /$ Permen/KP/2015, contain prohibition to anyone to catch lobsters, mud crabs and swimming crabs. The regulation about the length of lobster carapace is longer than $8 \mathrm{~cm}$ or weigh $200 \mathrm{~g}$ up.

Implementation management of genetic diversity in fisheries resource known that an overexploitation can cause genetic diversity of species (Palero at al. 2010). Implementing the regulations to prohibit the catch of female lobster, applying the minimum size captured lobster, and closing of fishing season. These rules were not capable to protected lobster from excessive exploitation. The use of genetic information associated with the spatial aspect to determine lobster species in the management connection (MPAs ) along the Mesoamerican Barrier Reef (MBRs ) Central America, found that a high level of connectivity for spiny lobster populations in MPAs in Central America. A high level of connectivity in MPAs important for international cooperation to manage lobster fisheries in Caribbean (Truelove et al. 2015).

\section{Method}

Sampling were done randomly on February to August 2015. Spiny lobster captured by gillnet with mesh size $3 / 4$ inches. 1137 lobsters captured were put into a cool box to be identified morphologically in situ based on Carpenter and Niem (1988). 40 of spiny lobsters from districts were analyzed genetically at Integrated Laboratory of Diponegoro University. Genetic analysis with subsequence stages, i.e. (1) Prepare DNA extraction by 5 steps i.e. DNA extraction : $1 \mathrm{~g}$ pleopod muscle crushed and inserted into mini tube containing DNA extractor. The solution mixed for 10 minutes, centrifuged 10 minutes, incubated at 950 for 20 minute, mixed 10 minutes, centrifuged 10 minutes. Suspension each sample transferred into micro tube. (2) Calculation mtDNA base pair (bp) : 
mtDNA bp template calculated with Nano drop, the number of $b p$ template as basis to compare with bp of mtDNA spiny lobster (566-571 bp, Abdullah et al. 2014). Suspension diluted if bp sample more than bp lobster and vice versa. (3) Amplification

Polymorphic bp mtDNA with Polymorphic Chain Reaction (PCR) based on Lavery et al., (2014) method and primer LCOOI and HCOOI with Promega. Mt DNA amplification fragments of samples determined with electrophoresis and read under ultraviolet ray. (4) sequencing template at PT. Genetic Indonesia. (5) Philogenetic analysis using Cod on code and MEGA 5.0 software and dendo-graph using Primer_e software.

Questionnaires data were collected from fisherman, lobster collector, lobster exporters, stakeholders, government and lobster expert. Data analyze by : 1 . SWOT (Strength Weakness Opportunity Threat) analysis (Rangkuti (2002). SWOT analysis was identify Strength, Weakness, Opportunity and Threat, which included identify the factors of strength and weakness in the matrix, Identify and analyze internal factors of Strength and Weakness, Identify and analyze external factors of Opportunities and Threat. SWOT analysis done to analysis of morphometric, analysis bio-diversity genetic and best opportunity and also simultaneously minimizing weaknesses and threats. Management policies consist of three stages (see Table 1). Input stage were collect data classification and pre-analysis by identify external and internal factors that affect to management of spiny lobster (Panulirus sp.) in the SCJ and SRJ waters. Identify of internal and external factor EFAS (External Factor Analysis Strategic) and IFAS factors (Internal Factor Analysis Strategic) matrix. The next step, scoring the internal factors and external strategies. Difference of scoring of each variable ratio with proportion value of each variable on the number of overall value. 2. AHP (Analytical Hierarchy Process) analysis (Rangkuti (2002). Prioritization of the strategy carried out gradually and systematically based on the hierarchical structure in five stages, namely: i) defining and problem solving ii) develop a hierarchical structure in this case are the goal, criteria and alternative actions, iii) the criteria are arranged in matrix form appeal pairs, iv) compare and assess, v) weighting the priority vector, vi) measure of consistency and vii) setting priorities and formulating alternative priorities the best management criteria.
Tabel 1. Stage of SWOT analyze (modified from Rangkuti, 2002)

\begin{tabular}{lll}
\hline No. & Stage of SWOT Analyze & \multicolumn{1}{c}{ Matriks } \\
\hline 1 & $\begin{array}{l}\text { Input Stage } \\
\text { Matrix of Evaluation }\end{array}$ & $\begin{array}{l}\text { Matrix of Evaluation } \\
\text { Internal factors }\end{array}$ \\
& $\begin{array}{l}\text { External factors } \\
\text { Analyse/Matching }\end{array}$ & \multicolumn{1}{c}{ Matrix of Internal dan } \\
3 & $\begin{array}{l}\text { Matrix of TOWS } \\
\text { Decision-making stage external factors } \\
\text { Analytical Hierarchy } \\
\text { Process }\end{array}$ & \\
\hline
\end{tabular}

\section{Rersult and Discussion}

SWOT analysis to identified factors of strength and weakness in a matrix. Internal factors of Strength and Weakness, external factors Opportunity and Threat analyzed. SWOT analysis is based on achieving the power and the best opportunity, also simultaneously to minimizing weaknesses and threats. Identify of the parameters of pre analysis resulted IFAS (Internal Factor Analyze Strategy) and EFAS (External Factor Analyze Strategy) strategies (see Table 2). The IFAS strategy were (i) SO strategy (strategy strength to take advantage of opportunities) : variables 1) developing technology of instrument, fishing equipment and human resources that are more economical, applicable to the beach and sea; 2) optimizing the utilization of habitat, time of arrest, the increase in the number of trip operations; 3 ) restricting of proportion of small size lobsters, 4) maintaining endemic genetic and identify new genetic of lobster. The EFAS strategy were (ii) WO strategy (strategies to minimize weaknesses to exploit opportunities), the variables were : 5) optimizing of utilization fishing ground by search of new fishing ground, 6) minimizing damage to habitat, 7) optimizing size that can be caught throughout the year, 8) developing more variation of genetic in order to support the morphological diversity. (iii) ST strategy (strategy of using force to overcome the threat) : 9) mapping the location of potential conflict of utilization, 10) concerting efforts to protect water quality lobster habitat, 11) restricting of optimum size of lobster can be captured, and 12) avoid the genetic specification of each district. (iv) WT strategy (strategies to minimize weaknesses and avoid threats), variables were : 13) optimizing the utilization of fishing ground, 14) optimizing the lobster habitat, 15) optimizing the optimum size of lobster that can be caught referring to the arrest of a friendly catch, 16) genetic specifications lobster by the district. 
Table 2. Matrix identification of Strength, Weakness, Opportunity and Treat in Southern of Central Java and Special Region of Jogjakarta waters.

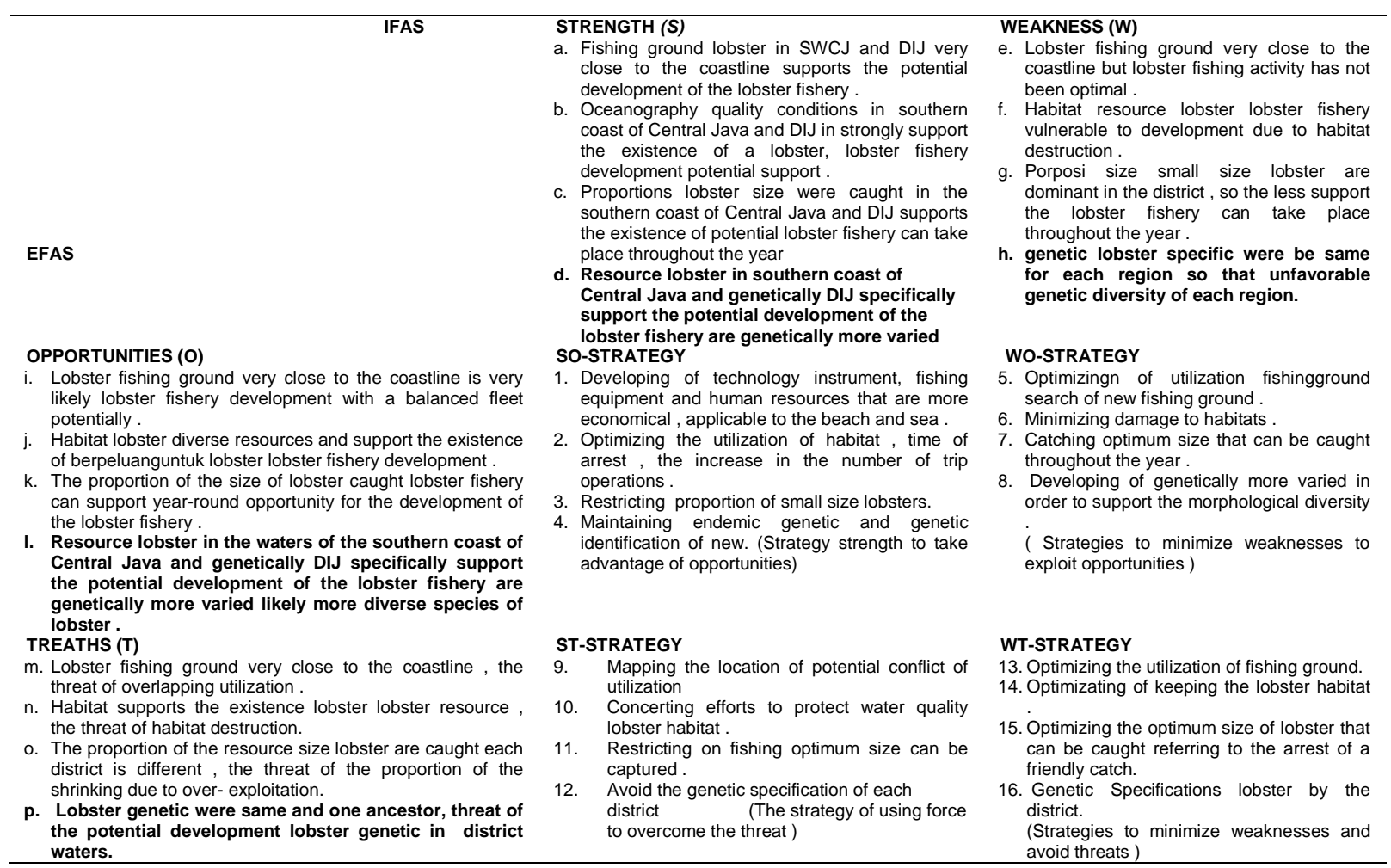

Table 3. Matrix rating factor of SWOT

\begin{tabular}{|c|c|c|c|c|c|c|}
\hline Factors of SWOT & \multicolumn{2}{|c|}{ Strategy } & Weigth & Rangk & Value & Scale analysis \\
\hline \multirow[t]{4}{*}{ Strength } & IFAS & 1 & 0.054 & 2 & 0.108 & Scale analysis of external \\
\hline & & 2 & 0.061 & 2 & 0.122 & variables : \\
\hline & & 3 & 0.065 & 2 & 0.130 & 1 : very strong \\
\hline & & 4 & 0.071 & 1 & 0.071 & 2 : strong \\
\hline \multirow[t]{4}{*}{ Weakness } & & 5 & 0.054 & 3 & 0.162 & 3 : weak \\
\hline & & 6 & 0.054 & 3 & 0.162 & 4 : very weak \\
\hline & & 7 & 0.060 & 3 & 0.180 & \\
\hline & & 8 & 0.071 & 4 & 0.284 & \\
\hline \multirow[t]{5}{*}{ Opportunity } & EFAS & 9 & 0.059 & 2 & 0.118 & Scale analysis of variable \\
\hline & & 10 & 0.064 & 2 & 0.128 & internal factors are : \\
\hline & & 11 & 0.058 & 2 & 0.116 & 1 : Low \\
\hline & & 12 & 0.065 & 2 & 0.130 & 2 : Medium \\
\hline & & 13 & 0.066 & 1 & 0.066 & \\
\hline \multirow[t]{3}{*}{ Thread } & & 14 & 0.060 & 3 & 0.180 & $3:$ High \\
\hline & & 15 & 0.068 & 3 & 0.204 & 4 : Very high \\
\hline & & 16 & 0.070 & 4 & 0.280 & \\
\hline Total & & & 1.000 & 39 & 2.441 & \\
\hline
\end{tabular}

Identification of appropriate strategies rank obtained analytical scales for each variable, strategy IFAS rated the first variable were number 4 and strategy EFAS variable number 13. Analysis of the interaction strategy which first priority was the Tread (index 0.264), the second was Strengths (index 0.251), and third was opportunity (index 0.246), and fourth was weakness ((index 0.239) (see Table 3). The priority were solve the Tread followed utilize existing Strength, take advantage of Opportunities invitation addressing Treats (see Table 4). The results of the strengths and weaknesses factors was $+0,012$, combination of opportunities and threats was - 0.018 , and priority coordinate in quadrant 2 , which the coordinate was $(+0.212 ;-0.028)$ (see Figure 1). Based on the coordinate, the strategies that can be applied 
in such conditions it is to minimize threats from the outside is to utilize internal strength.

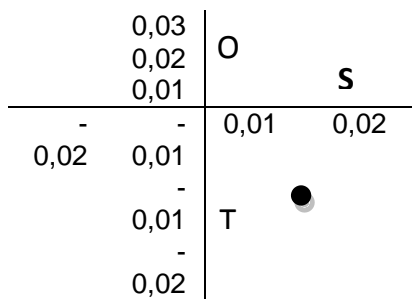

Figure 1. Coordinate of priority

Identification result of SWOT obtained from combination of factors, further identified strengths and opportunities gained a strategy based on the strengths and opportunities. Analyzing strategy of lobster resource management priority were resulted opportunity among strength. The SO strategy (see Table 5) of management based on first priority as highest value $(0,260)$ was developing of technological instrument, fishing equipment and human resources that are more economical, applying to the beach and sea (variable 1$)$. Second priority (0.256) was maintaining endemic genetic and genetic identification of new (variable 4). Priority three (0.251) was limiting the proportion of small size lobster were caught, and the last priority is optimizing the utilization of habitat, time fishing, the increase trip operations.
The analysis WO strategy (see Table 6), the first priority of management (0.262) was developing genetically more varied/diverse to support new morphological diversity. Second priority (0.258) was optimum size of fishing that can be caught throughout the year. Third priority $(0,253)$ was minimize the damage to the habitat, and fourth priority was optimizing fishing ground with search of new fishing ground. The analysis of ST strategy (see Table 7), that the first priority for management (0.264) was concerting efforts to protect water quality lobster habitat. Second priority (0.258) was mapping location that potential of conflicts. Third priority (0.256) was restricting fishing optimum size can be captured. Last priority in ST strategy was avoid the genetic specification of each district. The analysis WT strategy (see Table 8) that the first priority of management $(0.264)$ was optimizing the utilization of fishing ground. Second priority (0.258) with the optimizing of keeping the lobster habitat. Third priority $(0.256)$ was the optimizing of the optimum size of lobster that can be caught referring to friendly fishing. The last priority in the strategy of genetic specifications lobster WT was managing is not based on district management (see Table 8). Fisheries management is based on genetic diversity of spiny lobster approach in SCJ and SRJ by arranging the relative priority by combining the entire factors above strategy (seen Table 9).

Table 5. Matrix SO strategy

\begin{tabular}{llcc}
\hline No & SO Stategy & Value & Priority \\
\hline 1. & $\begin{array}{l}\text { Developing technology of instrument, fishing } \\
\text { equipment and human resources that are more } \\
\text { economical, applicable to the beach and sea. }\end{array}$ & 0,260 & 2 \\
$\quad \begin{array}{l}\text { Optimizing the utilization of habitat, time of } \\
\text { fishing, increase trip operations . }\end{array}$ & 0,248 & 1 \\
Restricting on the proportion of small size & 0,251 & 3 \\
3. $\quad \begin{array}{l}\text { lobsters are caught. } \\
\text { Maintaining endemic genetic and new genetic }\end{array}$ & 0,256 & 4 \\
\hline
\end{tabular}


Table 6. Matrix WO strategy

\begin{tabular}{llcc}
\hline No & WO Stategy & Value & Priority \\
\hline 1. & $\begin{array}{l}\text { Fishingground utilization optimization with the search } \\
\text { of new fishing ground. }\end{array}$ & 0,250 & 4 \\
2. & Minimizing of the damage to the habitat . & 0,253 & 3 \\
3. & $\begin{array}{l}\text { Fishing the optimum size that can be caught } \\
\text { throughout the year . }\end{array}$ & 0,258 & 2 \\
4. & $\begin{array}{l}\text { Developingt of genetically more varied / diverse to } \\
\text { support new morphological diversity . }\end{array}$ & 0,262 & 1 \\
\hline
\end{tabular}

Table 7. Matrix ST strategy

\begin{tabular}{lllc}
\hline No & ST Stategy & Value & Priority \\
\hline 1. & $\begin{array}{l}\text { Mapping the location of potential conflict of } \\
\quad \text { utilization }\end{array}$ & 0,258 & 2 \\
2. & $\begin{array}{l}\text { Concerting efforts to protect water quality lobster } \\
\quad \text { habitat . }\end{array}$ & 0,264 & 1 \\
3. & Restricting by optimum size can be captured. & 0,256 & 3 \\
4. & Avoid the genetic specification of each district & 0,252 & 4 \\
\hline
\end{tabular}

Table 8. Matrix WT strategy

\begin{tabular}{llcc}
\hline No & WT Strategy & Value & Priority \\
\hline 1. & Optimizing the utilization of fishing ground . & 0,258 & 2 \\
2. & Optimizing of keeping the lobster habitat . & 0,264 & 1 \\
3. & $\begin{array}{l}\text { Optimizing the optimum size of lobster that can be caught } \\
\text { referring to a friendly fishing. }\end{array}$ & 0,256 & 3 \\
4. & 0,252 & 4 \\
& & & \\
\hline
\end{tabular}

Table 9. Priority of strategy

\begin{tabular}{|c|c|c|c|c|}
\hline No & Sub Factor Strategy & Value & Score & Priority \\
\hline 1 & $\begin{array}{l}\text { Developing technology of instrumen, fishing equipment and human resources that are } \\
\text { more economical, applicable to the beach and sea. }\end{array}$ & 0,260 & 0,26 & 16 \\
\hline 2 & Optimizing the utilization of habitat, fishing time, the increase of fising trip & 0,248 & 0,992 & $4^{\star \star \star \star}$ \\
\hline 3 & Restricting on the proportion of small size lobsters. & 0,251 & 0,753 & 8 \\
\hline 4 & Maintaining endemic genetic and identification new genetic & 0,256 & 0,512 & 12 \\
\hline 5 & Fishingground utilization optimizing with the search of new fishing ground & 0,250 & 1 & $3^{\star \star \star}$ \\
\hline 6 & Minimizing of the damage to the habitat . & 0,253 & 0,759 & 7 \\
\hline 7 & Catching the optimum size that can be caught throughout the & 0,258 & 0,516 & 10 \\
\hline 8 & Development of genetic more varied/diverse to support new morphological diversity & 0,262 & 0,262 & 15 \\
\hline 9 & Mapping the location of potential conflict of utilization & 0,258 & 0,516 & 9 \\
\hline 10 & Concerting efforts to protect water quality lobster habitat . & 0,264 & 0,264 & 13 \\
\hline 11 & Restricting on fishing optimum size can be captured. & 0,256 & 0,768 & \\
\hline 12 & Avoid the genetic specification of each district & 0,252 & 1,008 & $2^{\star \star \star}$ \\
\hline 13 & Optimizing the utilization of fishing ground & 0,258 & 0,516 & 11 \\
\hline 14 & Optimizating of keeping the lobster habitat & 0,264 & 0,264 & 13 \\
\hline 15 & Optimizing the optimum size of lobster that can be caught referring to the arrest of a & 0,256 & 0,768 & \\
\hline \multirow[t]{2}{*}{16} & friendly catch. & 0,252 & 1,008 & $1^{*}$ \\
\hline & Genetic specification lobster is not based to districts management. & & & \\
\hline
\end{tabular}


Biodiversity spiny lobster in southern java water habitat is genetically acquired that each species has a kinship or still single ancestor. Based on the condition and is associated with spirit of regional autonomy which each local authority to manage its coastal water territory, then the spiny lobster fishery management aspect less precise if it is managed by area management in each district. SWOT and AHP analysis to determine priorities management acquired management is not based on a management authority of each district, but its required the cooperation of all district in SJW ad SRJ, or integrated management. The conditions for genetically that spiny lobster was a descendant although morphologically live scattered each district water.

\section{Conclusion}

Strategy of fisheries management can be obtained with the approach based on analysis SWOT and AHP. Strategy of fisheries management based on diversity genetic of spiny lobster in SCJ and SRJ waters with the first priority management was the genetic specification of lobster was not based to districts management. Second priority was avoid the genetic specification of each district. Third priority with a value was the utilization optimizing new fishing ground. Fourth priority were optimizing of habitat utilization, optimizing the time of fishing, and increasing fishing trips.

\section{Reference}

Abdullah, M. F., M. Alimuddin, A. J. Salama, and H Imai,. 2014. Genetic Isolation among the Northwestern, Southwestern and Central-Eastern Indian Ocean Populations of the Pronghorn Spiny Lobster Panulirus penicullatus. Int. J. Mol. Sci. 15(6) : 92429254.

Ambariyanto. 2010. Kebijakan Pengelelolan Organisme Laut Dilindungi. Kasus Kerang Raksasa (Protrcted Marine Organism Management Policy. The Case of Giant Clams). Semarang :Undip Press. (Bahasa Indonesia).

Breen, Benjamin and S. Hynes. 2014. Short comings in the European principles of Integrated Coastal Zone management (ICZM) : Assesing the implications for locally oriented coastal anagement using Biome Portofolio Analysis (BPA). Elsivier (2014) : 406-418.
Brooks.T. M., Mittermier, R. A., da Fonseca, G.A.B., and at. Al. 2006. Global Biodiversisty Conservation Priorities. Science. 313(5783):51-61.

Carpenter, K. E. and V. H. Niem. 1998. FAO Species Identification Guide for Fishery Purposes. The Living Marine Resources of The Western Central Pacific. Vol. 2. Cephalopods, Crustaceans, Holothurians and Sharks. FAO Species Identification Guide for Fishery Purposes. FAO. Rome. P. 972-1043.

Chow, Seinen., N. Suzuki., H. Imai., and T. Yoshimura. 2006. Molecular Species Identification of Spiny Lobster Phyllosoma Larvae of the Genus Panulirusfrom the Northwestern Pacific. Marine Biotechnology 8:260-267

de Lestang, S., N. Caputi., and J. W. Penn. 2015. A review of lobster fishery management: the Western Australian fishery for Panulirus cygnus, a case study in the development and implementation of input and outputbased management systems. ICES J. Mar. Sci. (2015) doi: 10.1093/icesjms/fsv057.

Duppont, D. P. 2013. Rights-based management in Canada:Lessons from two coasts and a centre. Elsivier 44:60-64.

Froese, R., N. Demirel., and A. Sampang. 2015. An overall indicator for the good enviromental status of marine water based on commercially exploited species. Elsivier 51:230-237.

Haryono, F.Eko Dwi., and H. P. Tjahya. 2008. Analisis Ukuran Spiny Lobster (Panulirus $\mathrm{sp}$ ) di perairan kabupeten Cilacap (Acuan Awal Pengelolaan Perikanan). (Analyse of Measurrement of Spiny Lobster (Panulirus $\mathrm{sp)}$ at Cilacap waters). Jurnal IImu-IImu Perairan. Sains Akuatik. 11 (1) : 65-74. (Bahasa Indonesia).

Jansen, H., S. Kidd., and T. Kvinge. 2014. A spatial typology for the sea : A contribution from Baltic. Elsivier 42 (2013) 190-197.

Landau, M. 1991. Introduction to Aquaculture. John Wiley \& Sons, Inc. New York. p: 363.

Lavery, S. D., A. Farhadi., H. Farahmand., T-Y. Chan., A. Azhdehakoshpour., V. Thakur., and A. G. Jeffs. 2014. Evolutionary Divergence of Geographic Subspecies 
within the Scalloped Spiny Lobster Panulirus homarus (Linnaeus 1758). PLOS ONE (9): 6 | e97247.

Leopold, M., J. Beckensteiner., J. Kaltavara., J. Raubani., and S. Caillon. 2013. Community-base management of nearshore fisheries in Vanuatu: What works?. Elsivier 42: 187-176.

Nanlohy, H., A.N. Bambang., Ambariyanto., and S. Hutabarat. 2015. Need to Conservation of Man-grove Ecosystem in Kotania bay, District of Western Seram, Mollucas : An approach the Local Wisdom and Behavior. Int. J marine Sci Ocean Technol. 2(1):1-4.

Palero, F., J. Lopes., P. Abelló., E. Macpherson., M. Pascual and M. A. Beaumont. 2009. Rapid radiation in spiny lobsters (Palinurus spp) as revealed byclassic and $A B C$ methods using mtDNA and microsatellite data. BMC Evolutionary Biology. 9:263.

Palero, F., J. Lopes., P. Abelló., E. Macpherson., M. Pascual and M. A. Beaumont. 2010. Rapid radiation in spiny lobsters (Palinurus spp) as revealed byclassic and $A B C$ methods using mtDNA and microsatellite data. BMC Evolutionary Biology. 9:263.

Rangkuti. F. 2002. Analisis SWOT Teknik Membedah Kasus BISNIS Reorientasi Konsep Perencanaan Strategis Untuk Menghadapi Abad 21. [SWOT Analyze Dissect Technique Bussines Case Reorientation Stategy of Planning Concept for 21 Century] PT. Gramedia, Jakarta.

Reddy, M. M. 2013. Molecular Phylogeny and Population Genetic Structure of the
Shallow-water Spiny Lobster Panulirus homarus in the South West Indian Ocean Region: Implications for Management. University of KwaZulu-Natal, Westville Campus, Durban, South Africa. Master Degree of Science (Marine Biology). School of Life Sciences. p. 20.

Sanchez, F., G. Morandeau., N. Bru., and M. Lissardy. 2013. A Restricted Fishing Area as toll for Fisheries managemant : Example of. Capbreton canyon, southern bay of Biscay. Elsevier 42 : 180-189.

Senevirathan, J. and D. Munasinghe. 2014. Genetik Diversity and Population Structure of Panulirus homarus Populations of Southern Sri Lanka and South India Revealed by the Mitocondrial CO1 Gene Region. Biological Medical Sciencews (FBMS-2014). Bangkok.

Salomo, M. and M. Dross. 2013. Challenges in cross-sectoral marine protection in Europe. Elsivier 42: 142-149.

Statistik Perikanan Indonesia, 2012. Kementrian Kelautan dan Perikanan. Direktorat Jenderal Perikanan tangkap. Jakarta. Vol. 13. No. 1.

Truelove, N. K., S. Griffiths., K. Ley-Cooper., J. Azueta., I. Majil., S. J. Box., D. C. Behringer., M. J. Butler IV., and R. F. Preziosi. 2015. Genetic evidence from the spiny lobster fishery supports international cooperation among Central American marine protected areas. Springer. Conservation Genetics. 16(2):347-358. 